\title{
The broad credit and bank capital channels of monetary policy transmission in the core and peripheral Euro Area*1
}

\author{
Silvo Dajcman ${ }^{2}$, Josip Tica ${ }^{3}$
}

\begin{abstract}
The goal of the paper is to identify and estimate transmission of monetary policy impulses through the broad credit and bank capital monetary policy transmission channels in the "core" and "peripheral" countries of the euro area. We employ the Euro Area Banking Lending Survey to identify the channels. Following identification, we employ the data in a panel vector autoregression model (PVAR) to investigate the pass-through of the standard and nonstandard monetary policy impulses to the gross domestic product (GDP), inflation, and volume of loans. The results imply that channels are interrelated and the broad credit channel is relatively stronger than the bank capital channel, while the relative importance of the bank capital channel is higher in peripheral than core euro area countries.
\end{abstract}

Key words: monetary policy, transmission channels, bank credit standards, nonstandard monetary policy

JEL classification: E44, E5, G21

\section{Introduction}

The goal of this paper is to identify and estimate transmission of monetary policy impulses through the broad credit channel and the bank capital channel of the monetary policy transmission mechanism in the "core" and "peripheral" euro area.

* Received: 29-05-2017; accepted: 21-12-2017

1 This research has been supported by Slovenian Research Agency under the research core funding programme P5-0023 (A) and by the Croatian Science Foundation under the funding programme "Sustainability of Croatian Economic Policy and Development", code IP-2013-11-7031, acronym SCrEPoDe.

${ }^{2}$ Assistant Professor, University of Maribor, Faculty of Economics and Business, Razlagova 14, 2000 Maribor, Slovenia. Scientific affiliation: economic policy, economic theory, finance. Phone: +38622290 275. E-mail: silvo.dajcman@um.si (corresponding author).

${ }^{3}$ Full Professor, University of Zagreb, Faculty of Economics \& Business, Trg J.F. Kennedy 6, 10000, Zagreb, Croatia. Scientific affiliation: macroeconomics, economic growth, environmental economics, Croatian economy. Phone: +3851238 3144.Fax:+38512383333.E-mail: jtica@efzg.hr. 
Traditional macroeconomic or monetary theory has largely ignored the effect of banking sector equity (capital) as well as the effect of the net worth of the nonfinancial sector (borrowers) on the supply of loans and demand for investment goods in the economy. Traditional models usually assume perfect capital markets and explain investment demand in the economy with interest rate (the interest rate or monetary channel of monetary policy).

On the other hand, a growing volume of literature studies informational imperfections in credit markets. Problems of asymmetric information between borrowers and lenders lead to an increase in the cost of external finance ${ }^{4}$ and a demand for collateral in the economy. According to theory, fluctuations in the value of borrowers' net assets are an important determinant of the supply of loans and real investments in the economy (broad credit channel). ${ }^{5}$ Furthermore, imperfect information on capital markets makes it difficult for banks to raise equity, which affects the supply of loans and the demand for investment goods (bank capital channel). ${ }^{6}$ Clearly, according to the imperfect capital (financial) market literature, the real demand for investments in the economy is a function of the net worth of borrowers and the capital adequacy of commercial banks in addition to the real interest rate.

Therefore, identification of all channels of the transmission of monetary policy is of utmost importance for the optimal design of monetary policy. The existence of an unidentified monetary transmission channel can amplify or dampen monetary policy impulses and result in suboptimal monetary policy. Furthermore, the existence of imperfect capital markets can provide policy makers with additional unconventional policy tools to increase the anti-cyclical possibilities of monetary policy in the situation of a zero nominal lower bound.

In response to deflation in combination with a liquidity trap in the euro area, the European Central Bank has expanded its monetary policy with non-standard monetary policy tools. Nevertheless, the bank lending statistics ${ }^{7}$ show that the passthrough of easing banks' financial conditions to the economy is diversified across the euro area (European Central Bank, 2015). This suggests that the monetary policy channels may work differently in the core and peripheral countries of the euro area or that the transmission of monetary policy in the peripheral euro area countries is still impaired due to larger credit market frictions in this area.

While the broad credit channel has received theoretical and empirical consideration, the literature on the bank capital channel, especially empirical studies, is relatively

$\overline{4}$ External finance describes funds that firm (bank in this case) obtains from outside investors and lenders and not from a firm's internal reserves and/or profits.

5 See Bernanke and Gertler (1989, 1995) and Peek and Rosengren (2012).

6 See, e.g., Bernanke and Lown (1991), Gambacorta and Mistrulli (2004), and Boivin et al. (2010).

7 See European Central Bank's database: https://www.ecb.europa.eu/stats/money/aggregates/bsheets/ html/growth_rates_A20.A.U2.0000.en.html. 
thin (see Gambacorta and Marques-Ibanez (2011) for a review). Markovic (2006) shows in a theoretical model that the broad credit channel and the bank capital channel are interrelated. The literature on the interrelation of the channels is thin (e.g. Kishan and Opiela, 2000; Meral, 2015), especially for euro area.

In this paper, we estimate the strength of the broad credit and bank capital channels. We use a panel vector autoregression model (PVAR) to examine the role of the broad credit and bank capital channels in the pass-through of standard and nonstandard monetary policy impulses to the gross domestic product (GDP), inflation, and the volume of loans in the core and peripheral euro area countries.

The research contributes to the extant literature on monetary policy transmission in four major ways. First, we use the Euro Area Bank Lending Survey (BLS) to identify both the broad credit and the bank capital channels. We thus contribute to the literature that uses bank lending surveys to investigate the monetary policy transmission. Second, we investigate whether the broad credit and the bank capital channels are interrelated. Third, we analyze whether the broad credit and the bank capital channels are affected differently by the standard and nonstandard (balance sheet policy) monetary policy. Fourth, the theory predicts that the broad credit and the bank capital channel are more relevant for economies with greater frictions in the credit markets. We therefore compare the relevance of the broad credit and the bank capital channels of monetary policy transmission for two groups of euro area countries (core and peripheral euro area countries) that were negatively, but differently, affected by the crises in the recent period. Our main hypothesis is that the relevance of the investigated transmission channels in the core and peripheral euro area differs.

The results show that the broad credit channel is strong and important in the core as well as the peripheral countries. Empirical evidence supporting the relevance of the bank capital channel is less strong; the results imply that the impact of the monetary policy impulses on the macroeconomic variables through this channel are about half the size of the broad credit channel and that the channel may be relevant only for the peripheral countries, implying that the euro area cannot be treated as a homogenous group when designing and evaluating the effects of monetary policy. We show that the channels are interrelated.

The remainder of the paper is organized as follows. Section 2 summarizes the extant literature, Section 3 presents the methodology, and Section 4 the data. Section 5 presents and discusses the empirical results, while Section 6 concludes the paper.

\section{Literature review}

The broad credit channel, also referred to as the (borrower) balance sheet channel (Peek and Rosengren, 2012), describes how the financial health of borrowers, reflected in their balance sheet, affects their ability to obtain loans. A widely adopted 
model of this type is the financial accelerator model of Bernanke and Gertler (1989, 1995) and Carlstrom and Fuerst (1997), which can be summarized as follows. In a non-frictionless credit market, banks face agency costs in preparing and enforcing optimal loan contracts (Bernanke and Gertler, 1989; Carlstrom and Fuerst, 1997). This is due to information asymmetry problems during the loan application processing (adverse selection problem) and monitoring and enforcing the loan contracts (moral hazard problems). To reduce the problems of asymmetric information, the lenders must be compensated. Thus, for the borrowers, external financial funds are expected to be more costly than internal funds (Bernanke and Gertler, 1989, 1995; Oliner and Rudebusch, 1996). Bernanke and Gertler (1989) prove that the external finance premium and the net worth (the balance sheet strength) of the borrower are inversely related. When monetary policy tightens, the balance sheet constraints of borrowers increase and their creditworthiness decreases because the interest expenses from the existing borrowings increase and the net cash flow decreases (Bernanke and Gertler, 1995; Boivin et al., 2010). The net worth of borrowers is pro-cyclical and amplifies the business-cycle fluctuations (a phenomenon called the financial accelerator). During economic or financial shocks to the economy, the frictions in the credit market increase, consequently increasing the external finance premium (Bernanke and Gertler, 1995; Bernanke, 2007). During these times, or in countries with greater information asymmetry problems (Markovic, 2006), the transmission of monetary policy impulses to the economy through the broad credit channel is expected to be amplified (Ciccarelli et al., 2015). ${ }^{8}$

Empirical studies that find the broad credit channel operational in the transmission of monetary policy impulses to the economy include, among others, Gertler and Gilchrist (1993, 1994), Kashyap et al. (1993), Cecchetti (1995), Bernanke and Gertler (1995), Oliner and Rudebusch (1996), Warner and Georges (2001), Hatzius (2005), Benito et al. (2006), and Christensen and Dib (2008). Studies that investigate the broad credit channel in the euro area and to which our study is related include Ciccarelli et al. $(2013,2015)$.

Ciccarelli et al. (2015), using BLS data, report that for 2002:Q4 - 2009:Q4 the broad credit channel in the euro area is operational. Similarly, Ciccarelli et al. (2013) also use data from BLS and analyze how during 2002:Q4 -2011:Q3 the channel was affected by the global and sovereign debt crisis in the euro area. Applying a panel vector autoregression (VAR) methodology and the rolling-window technique (windows spanning 20 quarters), their results show that the monetary transmission mechanism has been time-varying. They find that the broad credit channel is important for the stressed (peripheral euro area countries, including Portugal, Italy, Ireland, Greece, and Spain) euro area countries but only after the start of the global financial crisis.

\footnotetext{
8 Several other theoretical models of the channel have been developed by Kiyotaki and Moore (1997), Holmström and Tirole (1997), Christensen and Dib (2008), Cúrdia and Woodford (2010), Carlstrom et al. (2010), and De Fiore and Tristani (2013).
} 
In the bank capital channel, the balance sheet constraints of banks - they arise because capital requirements and the cost of issuing new equity - negatively affect their loan supply. Gambacorta and Mistrulli (2004) and Van den Heuvel (2002a) note that the bank capital channel rests on three premises: (i) a non-frictionless bank equity market, (ii) a maturity transformation performed by banks that exposes them to interest rate risk, and (iii) prudential regulatory capital requirements. Van den Heuvel (2002a) shows that under these conditions a contractionary monetary policy worsens the bank capital soundness due to lower bank profits that contract because of reduced interest margins. The effect reverses after an expansionary monetary policy impulse. Additionally, an expansionary monetary policy may fuel the financial market with additional liquidity that also finds its way to capital markets, thus raising the demand for assets and leading to asset price increases. This sequentially improves bank capital adequacy.

In his theoretical model, Van den Heuvel (2007) shows that the bank capital channel may be more relevant when the capital requirements are more binding, that is, for banks (or the country's banking sectors) with lower capital adequacy ratios. Markovic (2006) argues that interrelations may exist between the broad credit channel and the bank capital channel. For example, during recession, borrowers' net worth decreases (their balance sheet constraints increase) and their capability to pay back loans decreases. The resulting increase in the share of non-performing loans increases banks' capital constraints. A higher leverage ratio increases the average cost of borrowing for commercial banks. Finally, higher funding costs for banks result in higher lending rates for borrowers, with negative consequences for investment demand and real output. As the external finance premium increases, the average cost of funding for borrowers increases and the net worth of borrowers declines further.

The list of empirical studies on the bank capital channel is short, but includes Van den Heuvel (2002b), Gambacorta and Mistrulli (2004), Kishan and Opiela (2006), Watanabe (2007), and Kanngiesser et al. (2017). For the euro area Kanngieser et al. (2017) show that the channel is functional.

The empirical literature tests for the bank capital channel (Van den Heuvel, 2002b; Gambacorta and Mistrulli, 2004; Kishan and Opiela, 2006; Watanabe, 2007) by analyzing how the individual bank or aggregate banking sector capital-to-assets ratios influence the effect of monetary policy on the macroeconomic variables. However, banks' capital constraints may increase not only due to a fall in the capital adequacy ratio but also if banks wish for some other reason to increase equity (Markovic, 2006), in which case the capital constraint increases before the capital-to-assets ratio is increased. The banks' capital-to-assets ratios therefore may not reflect fully the capital constraints the banks face. To overcome the empirical challenges of bank capital channel identification, Peydró (2010) and Kanngieser et al. (2017) suggest using BLS responses. 


\section{Methodology}

Our research follows some recent studies on monetary policy transmission channel(s) that use the bank lending survey data to identify the channel(s) (see among others Lown and Morgan, 2006; Ciccarelli et al., 2013, 2015; Cappiello et al., 2010; Basset et al., 2014; Maddaloni and Peydró, 2011, 2012; Dajcman, 2016). Specifically, we use the results from the BLS to identify the broad credit and the bank capital channels in the euro area.

Several answers in the BLS can be related to the borrowers' balance sheet strength: net worth, collateral, and credit risk of borrowing firms (see Ciccarelli et al., 2013, 2015; Maddaloni and Peydró, 2012) and, thus, can be used to investigate the functioning of the broad credit channel. We follow Ciccarelli et al. $(2013,2015)$ and proxy for the balance sheet constraints of non-financial enterprise borrowers by composing a single indicator variable, denoted BBSC, that measures net tightening (or possibly easing) of credit standards induced by borrowers' balance sheet constraints. The broad credit channel predicates that monetary policy tightening results in reduced credit activity and output. We test for the existence of this channel by estimating a monetary policy PVAR model and then analyzing the cumulative impulse response functions of the variable BBSC to a monetary policy shock and cumulative impulse response functions of the business loans volume, real GDP, and price level (HICP) to a shock to the BBSC.

In order to identify the bank capital channel we follow Peydró (2010) and Kanngieser et al. (2017). We assume that the effect of bank capital constraints on their lending is reflected in the BLS response on the credit standards factor impact of capital position. This variable, denoted BCPC, measures changes in credit standards induced by bank capital position constraints. We inspect the bank capital channel hypothesis by estimating the monetary policy VAR model and then analyzing the cumulative impulse response functions of the variable BCPC to a monetary policy shock and cumulative impulse response function of the business loans volume, real GDP, and HICP to a shock to the BCPC.

The functioning of the monetary policy transmission channels is estimated with a PVAR model, specified as (see e.g. Love and Zicchino, 2006):

$$
Y_{i t}=\sum_{p=1}^{L} A_{p} Y_{i t-p}+\eta_{i}+u_{i t}, i=1, \ldots, N t=1, \ldots, T
$$

estimated on a dataset of $N$ different euro area countries, $T$ quarters, and $k$ explanatory variables. $Y_{i t}$ is a $\mathrm{k} \times 1$ vector of stationary endogenous variables, $A_{p}$ is a $\mathrm{k} \times \mathrm{k}$ matrix of regression coefficients from lag 1 to lag $L, \eta_{\mathrm{i}}$ is a $\mathrm{k} \times 1$ vector of country-specific fixed effects, and $u_{i t}$ is a $\mathrm{k} \times 1$ vector of idiosyncratic errors with the properties: $\mathrm{E}\left[u_{i t}\right]=0, \mathrm{E}\left[u_{i t}^{\prime} u_{i t}\right]=\sum$ and $\mathrm{E}\left[u_{i t}^{\prime} u_{i s}\right]=0$ for $t>s$. The number of lags, $L$, is determined by the Akaike information criteria (AIC) as suggested by Andrews and Lu's (2001) minimization criteria based on AIC (see Abrigo and Love, 2016). 
Two sets of endogenous explanatory variables are exploited. The first set consists of typical macroeconomic variables (GDP and HICP) and a variable for the monetary policy stance. ${ }^{9}$ A typical monetary policy stance variable used in the extant literature is monetary policy rate. We use EONIA rate. To correctly capture the monetary policy stance, ${ }^{10}$ we also simultaneously use the sum Eurosystem consolidated balance sheet items that are directly related to monetary policy. The second set of endogenous variables contains the volume of business loans outstanding and the variables $\mathrm{BBSC}$ and $\mathrm{BCPC}$.

Choleski (triangular) decomposition is used to identify the VAR model and the variables are ordered as in Christiano et al. (1996), Lown and Morgan (2006), Basset et al. (2014), and Dajcman (2016); that is, the macroeconomic variables are ordered first, followed by the monetary policy stance variables and the credit market variables. We place the real GDP as the first, assuming it to be the most "exogenous" variable (i.e., shocks to the output affect all other variables contemporaneously, but not the reverse), followed by the HICP. The monetary policy stance variable is ordered third (EONIA preceding Eurosystem balance sheet), assuming the monetary policy responds to the shocks to the GDP and price index and that the monetary policy stance shocks affect contemporaneously the credit market variables. Business loans are ordered fourth, followed by variables BBSC and BCPC. ${ }^{11}$

9 These three variables are applied in the extant literature; see, e.g., Christiano et al. (1996), Leeper et al. (1996), Lown and Morgan (2006), Bassett et al. (2014), Ciccarelli et al. (2013, 2015), and Dajcman (2016).

${ }^{10}$ While before the global financial crisis there was a growing consensus that in the euro area EONIA was a good indicator of the Eurosystem's monetary policy stance (Busch et al., 2010; Ciccarelli et al., 2013, Ciccarelli et al., 2015), it is argued that once the policy rate hits the zero lower bound EONIA may not consistently reflect the central bank's monetary policy stance (Lombardi and Zhu, 2014; Gambacorta et al., 2014; Wu and Xia, 2015). To quantify the monetary policy stance when the zero lower bound is reached, the empirical literature has developed two approaches. The first approach measures the monetary policy stance with the shadow (short) rate (Lombardi and Zhu, 2014; Bauer and Rudebusch, 2015; Wu and Xia, 2015). The second rests on the premise that the non-standard monetary policy is reflected in the central bank's balance sheet size and structure (e.g., Boeckx et al., 2014; Gambacorta et al., 2014). Because this research also aims to answer how the non-standard policies, reflected in the size of the Eurosystem's balance sheet, affect the broad credit and the bank capital channels, in our baseline model we proxy the monetary policy stance of the Eurosystem by using simultaneously EONIA and the sum of the Eurosystem's balance sheet items that are directly related to monetary policy. In applying this approach, we assume that the monetary policy stance of the Eurosystem is partly reflected by EONIA and partly by its balance sheet size.

${ }^{11}$ By ordering the variable BBSC before the $\mathrm{BCPC}$ variable, we assume that credit standards changes induced by the borrowers' balance sheet constraints are more "exogenous" than credit standards changes induced by bank capital position constraints. This assumption implies that banks' capital position constraints are more likely to respond to the borrowers' balance sheet constraints (e.g., after an economic shock that reduces the profits and the net cash flow of enterprise borrowers and their net worth, the capability to return loans and to obtain new loans drops and this in turn negatively affects the bank capital position) than the opposite (e.g., increased regulatory capital adequacy standards increase bank capital constraints, leading to constrained supply and consequently increased borrowers' balance sheet constraints). 
Equation (1) is estimated with the generalized method of moments on the Helmert transformed variables (i.e., transformed by forward orthogonal differentiating) to resolve the issue of exogeneity that arises due to lagged dependent variables (see Nickell, 1981; Abrigo and Love, 2016). The Stata codes of Love and Zicchino (2006) and Abrigo and Love (2016) are used. After the model is estimated, the cumulative impulse response functions are drawn.

\section{Empirical data and analysis}

\subsection{Empirical data}

In our research, we use data for 11 euro area countries that have been a part of the euro area since the beginning of 2003: ${ }^{12}$ Austria, Belgium, France, Germany, Greece, Ireland, Italy, Luxembourg, the Netherlands, Portugal, and Spain. We divide the countries into two subsamples: core euro area countries (Austria, Belgium, France, Germany, the Netherlands, and Luxembourg) and peripheral euro area countries (Greece, Ireland, Italy, Portugal, and Spain).

Table 1: Description of variables used in model (1)

\begin{tabular}{|l|l|l|}
\hline \multicolumn{1}{|c|}{ Variable } & \multicolumn{1}{|c|}{ Description of the variable } & $\begin{array}{c}\text { Source of primary data } \\
\text { and data descriptions }\end{array}$ \\
\hline Real GDP & $\begin{array}{l}\text { The first difference of the natural logarithm } \\
\text { of the quarterly chain-linked (real) GDP } \\
\text { (seasonally and working day adjusted) }\end{array}$ & Eurostat \\
\hline HICP & $\begin{array}{l}\text { The first difference of the natural logarithm } \\
\text { of the quarterly Harmonized Index of } \\
\text { Consumer Prices (HICP) }\end{array}$ & Eurostat \\
\hline EONIA & $\begin{array}{l}\text { Average quarterly value of EONIA (Euro } \\
\text { OverNight Index Average is the euro area } \\
\text { interbank lending rate with maturity overnight) }\end{array}$ & European Central Bank \\
\hline $\begin{array}{l}\text { Eurosystem's balance } \\
\text { sheet items directly } \\
\text { related to monetary } \\
\text { policy }\end{array}$ & $\begin{array}{l}\text { The first difference of the natural logarithm of } \\
\text { the sum of items for the longer term refinancing } \\
\text { operations and securities held for monetary } \\
\text { policy purposes from the Eurosystem's balance } \\
\text { sheet, i.e. items A5.2 and A7.1 from the } \\
\text { Eurosystem's consolidated balance sheet (see } \\
\text { European Central Bank, 2012). }\end{array}$ & European Central Bank \\
\hline $\begin{array}{l}\text { Volume of business loans } \\
\text { outstanding }\end{array}$ & $\begin{array}{l}\text { The first difference of the natural logarithm } \\
\text { of the volume of outstanding loans to non- } \\
\text { financial enterprises }\end{array}$ & European Central Bank \\
\hline
\end{tabular}

$\overline{12}$ The start of the observation period is determined by the availability of the data on the volume of business outstanding. 
Silvo Dajcman, Josip Tica $\bullet$ The broad credit and bank capital channels of monetary policy...

\begin{tabular}{|l|l|l|}
\hline \multicolumn{1}{|c|}{ Variable } & \multicolumn{1}{|c|}{ Description of the variable } & \multicolumn{1}{|c|}{$\begin{array}{c}\text { Source of primary data } \\
\text { and data descriptions }\end{array}$} \\
\hline BBSC & $\begin{array}{l}\text { The (non-financial enterprise) borrower } \\
\text { balance sheet constraints indicator. It is } \\
\text { expressed as diffusion index and formed as } \\
\text { a simple average of the BLS responses }{ }^{13} \text { on } \\
\text { the following credit standards factors: impact } \\
\text { of risk on collateral demanded, impact of } \\
\text { general economic activity, and impact of } \\
\text { industry or firm-specific outlook }{ }^{14}\end{array}$ & $\begin{array}{l}\text { European Central Bank, } \\
\text { BLS }\end{array}$ \\
\hline BCPC & $\begin{array}{l}\text { The bank capital position constraint } \\
\text { indicator. This is a BLS response on the } \\
\text { credit standards factor impact of capital } \\
\text { position, expressed as a diffusion index. }\end{array}$ & BLS \\
\hline
\end{tabular}

Notes: Only real GDP is seasonally and working day adjusted. Other time series are not adjusted, because in the primary data source (European Central Bank Statistical Data Warehouse) these data are not adjusted on the per-country basis. This approach (of non-adjusting other time series for season and working days) is applied in some of the referenced papers (e.g. Kanngiesser et al. (2017), or Dajcman (2016)). We argue that this is appropriate because the European Central Bank Lending Survey explicitly asks the bankers to access the factor contributions to the bank credit standards irrespective of the season. In most papers referenced in the paper, no attention is paid to seasonal adjustment - the authors do not state exactly or at all which time series are seasonally adjusted (e.g. Ciccarelli 2013, 2015).

Source: Authors variable transformations on data from primary data providers

\footnotetext{
${ }^{13}$ The respondents (banks) in the BLS answer how the credit standards and the credit standards factors have changed in their bank during the last quarter. They choose from five offered answers: increased considerably, increased somewhat, remained unchanged, decreased somewhat, and decreased considerably. A "diffusion" index is then calculated as the weighted difference between the answers, increased considerably (that are given a weight of 1 ) and increased somewhat (a weight of 0.5 ), and the answers, decreased considerably (a weight of -1) and decreased somewhat (a weigh of -0.5). A positive value of the diffusion index for a credit standards factor can be explained as the factor contributing to net tightening of the credit standards, while a negative index value indicates the factor contributes to net easing of credit standards.

${ }^{14}$ This approach of reducing the number of credit standards to one by taking a simple average of the credit standard factors' contribution to credit standards follows the approach of Ciccarelli et al. $(2013,2015)$. They, however, use the responses form BLS measured in net percentages. We also tried to form the composite variable by a principal component analysis of the three credit standards factors and then taking the first principal component that explains the greatest share of volatility in the credit standards factors and standardizing the BBSC and the BCPC variables. The results (impulse responses), not presented here, of this exercise support the findings based on BBSC formed on simple averages from the BLS survey, but because principal component analysis and standardization of BBSC and BCPC entail a loss of information on the size of diffusion index changes in the core and peripheral countries, we prefer to present the results that are based on the BBSC formed from the simple averages.
} 
The panel data used in empirical analysis is balanced and spans 2003:Q1 2015:Q4. Maximum time span is constrained by the availability of quarterly data on business loans. Description of variables used in model (1) is presented in Table 1. Transformations of the primary data are made in order to make the series stationary ${ }^{15}$.

Dynamics of the sampled average euro area real GDP and business loans volume (logarithmic) growth and the average value of the BBSC and BCPC are presented in Figure 1.

Figure 1: Logarithmic change of GDP and business loans volume and evolution of the $\mathrm{BBSC}$ and $\mathrm{BCPC}$ of sampled euro area over time

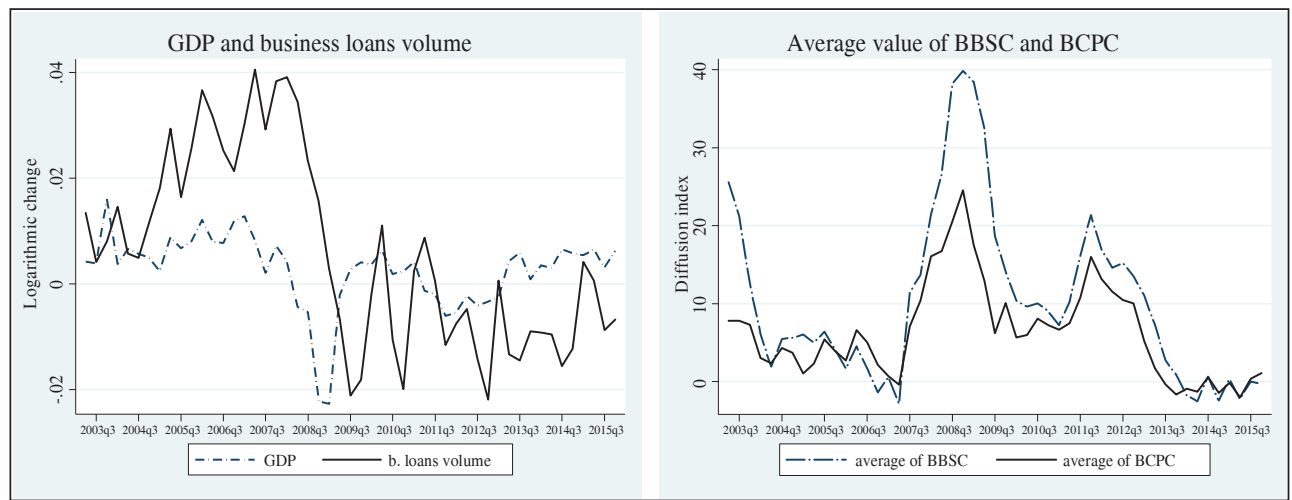

Notes: Presented are the simple averages of the variables across the sample of euro area countries. In the left plot, the logarithmic change of e.g. 0.01 of real GDP corresponds to a $1 \%$ percent logarithmic growth of GDP.

Source: Own calculations based on the primary data from Eurostat and European Central Bank

The bank business loans volume growth are negatively lag-correlated to the BBSC as well as $\mathrm{BCPC}^{16}$ (Table 2).

\footnotetext{
${ }^{15}$ The stationarity of the panel variables is asserted by the Im-Pesaran-Shin test (Im et al., 2003) while the common variables (EONIA and quarter-on-quarter logarithmic growth of the sum of the Eurosystem's consolidated balance sheet items) by the KPSS test. No cointegration is found between the variables integrated on the order of 1 in levels. Westerlund's (2007) test and Persyn and Westerlund's (2008) codes are used for the purpose. The results of the tests of stationarity and cointegration are available upon request.

${ }^{16}$ It is reasonable to expect the banks' loans volume to respond with a lag to the banks' credit standard changes.
} 
Table 2: Contemporaneous and lagged correlation between BBSC (BCPC, respectively) and the growth of business loans volume

\begin{tabular}{|c|c|c|}
\hline $\begin{array}{c}\text { Lag of bank business loans } \\
\text { volume growth variable }\end{array}$ & $\begin{array}{c}\text { Correlation between BBSC and } \\
\text { the growth of bank business loans }\end{array}$ & $\begin{array}{c}\text { Correlation between BCPC and } \\
\text { the growth of bank business loans }\end{array}$ \\
\hline $\begin{array}{c}0 \\
\text { (contemporaneous } \\
\text { correlation) }\end{array}$ & 0.034448 & -0.70629 \\
\hline 1 & -0.13712 & -0.72815 \\
\hline 2 & -0.27592 & -0.59613 \\
\hline 3 & -0.38877 & -0.52422 \\
\hline 4 & -0.46193 & -0.37905 \\
\hline
\end{tabular}

Source: Authors' calculations based on European Central Bank data

The (Pearson's) correlation increases (reduces) as the time-lead of the BBSC (BCPC) variable increases.

\subsection{Empirical analysis}

The PVAR model, represented by equation (1), is estimated with the lag set to 1, as indicated by Andrews and Lu's (2001) rule. The resulting cumulative impulse response functions are presented in Figures 2-5. ${ }^{17}$

Figure 2, in the left column plots, depicts the effects of the monetary policy rate and the central bank balance sheet shocks on the credit standards changes induced by the borrower balance sheet constraints (BBSC), and in the right column plots, it shows the effects of the monetary policy rate and the central bank balance sheet shocks on the credit standards changes induced by the banks' capital position constraints (BCPC). The results are presented separately for the euro area as a whole (consisting of 11 countries), for the core, and for the peripheral.

Evidently, a one standard deviation increase in the EONIA rate increases BBSC as well as BCPC. The result implies that a monetary policy contraction leads banks to tight credit standards due to increased borrowers' balance sheet constraints and banks' capital position constraints.

Although the directions of the cumulative impulse responses of the BBSC and the $\mathrm{BCPC}$ to the shock to EONIA are the same for the core and the peripheral euro

\footnotetext{
${ }^{17}$ We also computed the forecast-error variance decomposition, based on the results of model (1). They, however, are not in our main interest and therefore just present the key findings for the euro area as whole. The results show that contribution of the BBSC shock to the variance of (logarithmic growth) volume of business loans (GDP and HICP, respectively) is 5.9 (3.3 and 6.9, respectively) percent at 16 quarters after the shock, while the contribution of the BCPC at the same horizon is 0.08 ( 0.3 and 0.37 , respectively) percent.
} 
area countries, the magnitude of the cumulative impulse responses differs. Banks in the peripheral euro area see the borrowers' balance sheet and the banks' capital constraints as more negatively affected, and in turn increase credit standards in response to the Eurosystem's policy rate hike relatively more that in the euro area core: When EONIA is shocked (i.e., increases) by a standard deviation (for the observed sample, the standard deviation is 1.4 percentage points), the BBSC by the end of 16 quarters after the shock increases more in the peripheral (diffusion index is approximately 22) than in the core countries (diffusion index is approximately 6), meaning that a greater weighted share of banks increases credit standards for loans to enterprises in the peripheral than in the core euro area countries. The same holds true for the response of the BCPC to a monetary policy rate shock: The diffusion index of $\mathrm{BCPC}$ for the peripheral countries is approximately 13 while for the core it is approximately 6.

Since the start of the global financial crisis, the Eurosystem has applied and extended the non-standard monetary policy. While EONIA captures the standard monetary policy and the negative interest policy ${ }^{18}$ of the Eurosystem, its monetary policy stance is not completely captured by the EONIA rate alone. To more fully capture the monetary policy stance, we also consider the effect of the balance sheet policy, which is reflected in the size of the balance sheet items related directly to monetary policy. The cumulative impulse response function of the BBSC and the BCPC shows that the Eurosystem's programs that led to expansion of its consolidated balance sheet (including, e.g., the long-term refinancing operations, the targeted longer term refinancing operations (TLTRO and TLTRO2), and the expanded asset purchase program) results in an increase in the variables BBSC and BCPC. The effect, however, is smaller than the one from the policy rate change and more delayed. Indeed, the effect of expansion of the Eurosystem balance sheet shock on the BBSC in the whole euro area becomes significant only after 14 quarters. Again, we note that the expansionary monetary policy shock (increase in the balance sheet) has a large and significant effect only in the periphery of the euro area; the effect is smaller and insignificant in the core area. The effect of the expansionary balance sheet policies on the $\mathrm{BCPC}$ is not significant.

\footnotetext{
${ }^{18}$ The Governing Council lowered the Eurosystem's rate for the marginal deposit facility below zero in June 2014. It has been lowered several times since then. One can, therefore, argue that at least since June 2014 the Eurosystem has been running a negative interest rate policy.
} 
Figure 2: Cumulative responses of the BBSC and BCPC to a shock to EONIA and the Eurosystem balance sheet volume

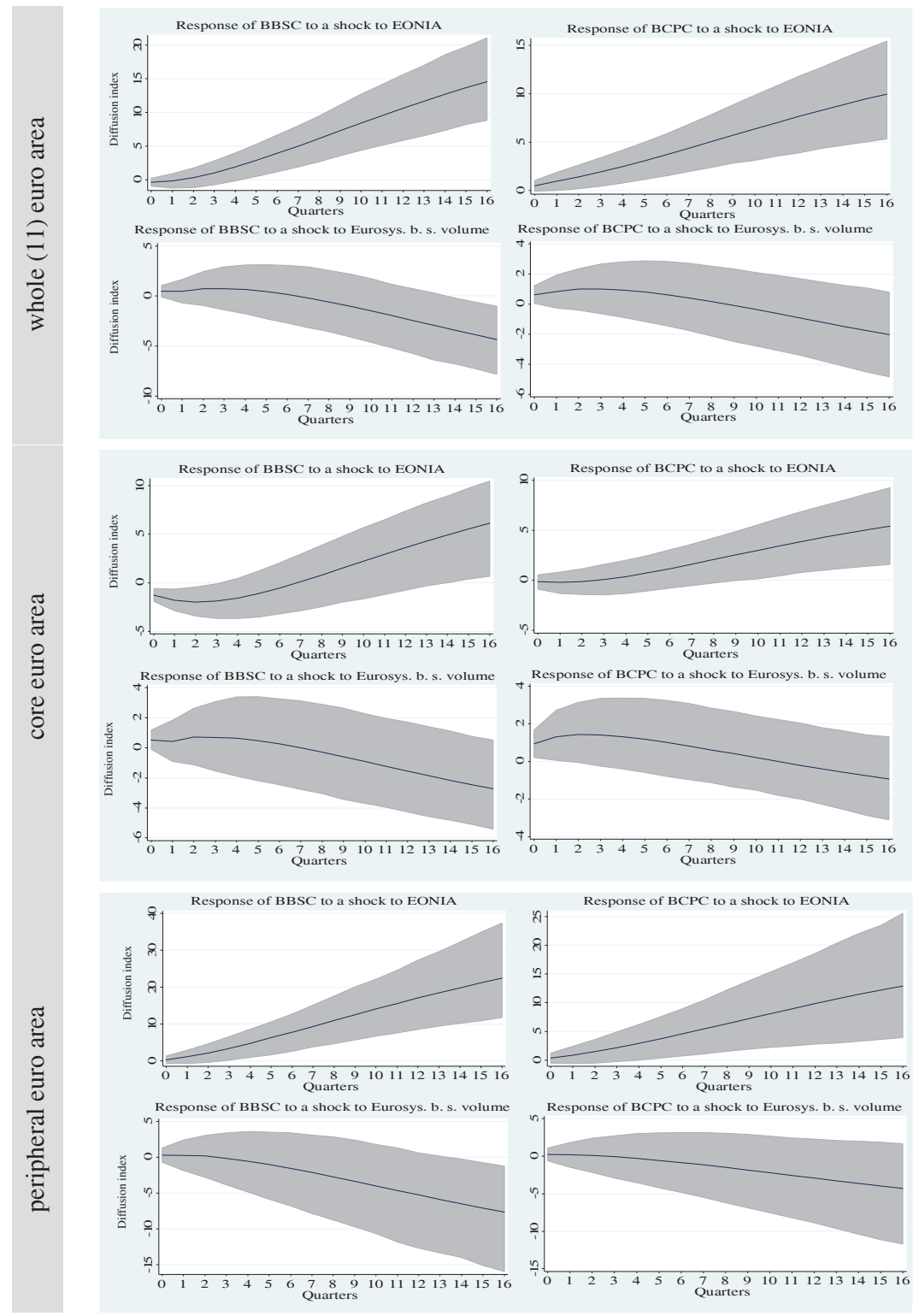

Notes: In each panel, the plots convey the (cumulative impulse) response functions of the BBSC and the BCPC to a one standard deviation adverse shock (i.e., increase) to the policy rate of the Eurosystem and the Eurosystem's expansionary balance sheet shock over the period of 16 quarters from the shock. The black lines present the estimated cumulative impulse response functions, while the shaded area shows a 95 percent (Monte Carlo) bootstrapped (with 1000 replications) confidence interval.

Source: Authors' calculations 
The results presented in Figure 2 suggest that the broad credit channel may be more relevant than the bank capital channel for the monetary policy transmission in the euro area. We must elaborate on this by inspecting the pass-through process of the monetary impulse via balance sheet constraints of banks and enterprise borrowers on the aggregate volume of bank loans, the real GDP and the price level.

Figure 3 traces out the cumulative impulse responses of the aggregate volume of business loans outstanding to the BBSC and the BCPC shocks. A shock to the BBSC leads to an immediate reduction in the volume of loans. The accumulation of the effect protracts even four years after the shock. In the euro area the volume of loans by the end of the fourth year after the shock drops by approximately 5 percent: It drops by only approximately 3 percent in the core and 7 percent in the peripheral euro area. A shock to the BCPS also negatively affects the volume of business loans. The effect, however, is only approximately one third that from the shock to the BBSC and the cumulated impulse responses are insignificant. The results suggest that after a supply of loans is constrained via credit standards tightening due to increased borrower balance sheet constraints the aggregate credit activity decreases across the board in the core and peripheral euro areas, more so in the latter group of countries. If the supply of loans is constrained via credit standards tightening due to banks' capital constraints (i.e., increase in BCPC), the aggregate credit activity in the euro area as a whole decreases less and especially due to banking loan book reduction (deleveraging) in the peripheral euro area. However, the statistical evidence (significance of impulse responses) of the banks' capital constraint shocks on the credit activity is weak, especially for the core countries.

The literature (see, e.g., Markovic, 2006) predicts that when banks' capital constraints increase, borrowers' balance sheet constraints increase as well. This can be verified empirically by the cumulative impulse response functions calculated from estimates of the model represented by equation (1). The results are summarized in Figure 4. 
Figure 3: Cumulative responses of volume of outstanding loans to non-financial enterprises to a shock to the BBSC and the BCPC

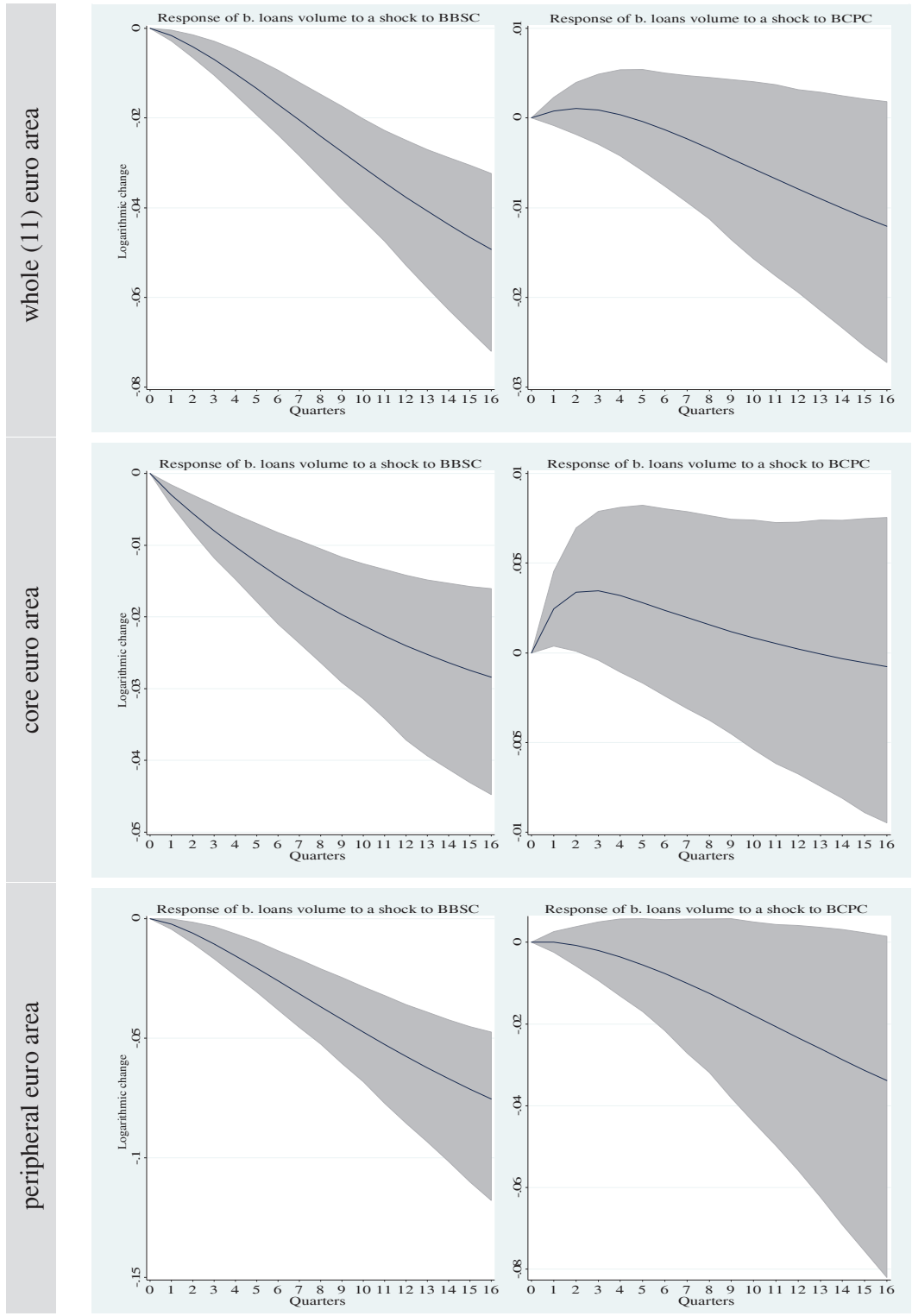

Notes: The plots depict the (cumulative impulse) responses of the volume of loans to nonfinancial enterprises to a one standard deviation adverse shock (i.e., increase) to the BBSC and BCPC, respectively, over the period of 16 quarters from the shock. The black lines present the cumulative impulse response functions, while the shaded area shows the 95 percent (Monte Carlo) bootstrapped (with 1000 replications) confidence interval. Logarithmic change of 0.01 corresponds to 1 percent logarithmic growth.

Source: Authors' calculations 
Figure 4: Interrelation between the BBSC and BCPC

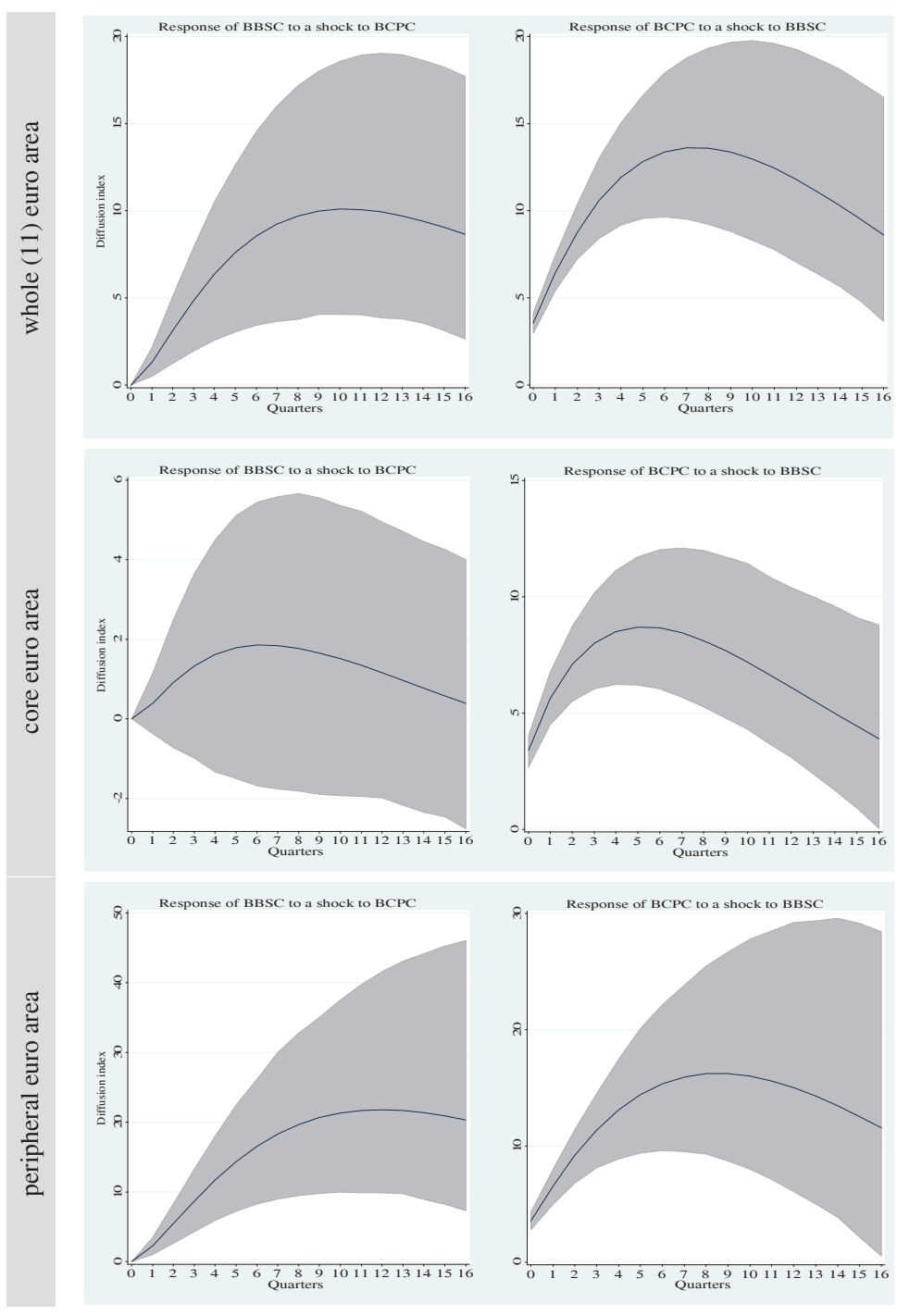

Notes: The plot panels depict the (cumulative impulse) responses of the BBSC to a one standard deviation shock to the BCPC and reverse over the period of 16 quarters from the shock. The black lines present the estimated cumulative impulse response functions, while the shaded area shows the 95 percent (Monte Carlo) bootstrapped (with 1000 replications) confidence interval. One important reason for relatively wide confidence intervals in the panels of Figure 4 - this is particularly the case for the impulse response of the BBSC to the BCPC shock - could be that especially for the variable BCPC the variability is relatively low. This is especially true for some countries in the sample for which the number of participating banks is small (e.g. Slovenia, Ireland, and some other small countries) from which only a small number of banks participate in the European Bank Lending Survey.

Source: Authors' calculations 
The results show that the shock to the variable BCPC leads to a significant increase in the variable BBSC. The significant cumulative impulse response, however, is obtained only for the euro area as a whole and the peripheral countries; this supports the notion that borrowers' financial constraints are severely affected after negative bank capital shocks only in credit markets with more severe frictions. Figure 4 also shows that a detrimental shock to the BBSC always increases the BCPC; that is, when banks tighten credit standards for loans to non-financial enterprises due to enterprises' increased balance sheet constraints, the credit standards are in turn likely to tighten also because of the increased number of banks with capital position constraints. The results thus indicate that the borrowers' balance sheet constraints and the banks' capital position constraints are interrelated. Following Markovic (2006) and Peydró (2010), this is proof that the broad credit and the bank capital channels are interrelated.

Figure 5 summarizes the pass-through of monetary policy impulses via the broad credit channel and the bank capital channel on the real GDP and inflation. After the BBSC or BCPC is shocked, real GDP growth responds more strongly and sooner than price index growth (i.e., inflation). In the euro area as a whole, in four years' time after the shock to the BBSC, the economic growth decreases by approximately twice as much as inflation. Shocks to the BCPC do affect real GDP growth but do not significantly influence inflation.

We also note a difference in the real GDP growth response to the shock: In the periphery, economic growth statistically significantly drops by approximately 1.2 percent by the end of four years after the shock, while in the core euro area a 0.3 percent statistically non-significant reduction is calculated. Shocks to the BCPC negatively affect real GDP growth in the euro area as a whole. 
Figure 5: The impulse response functions of real GDP and HICP to a shock in the $\mathrm{BBSC}$ and $\mathrm{BCPC}$

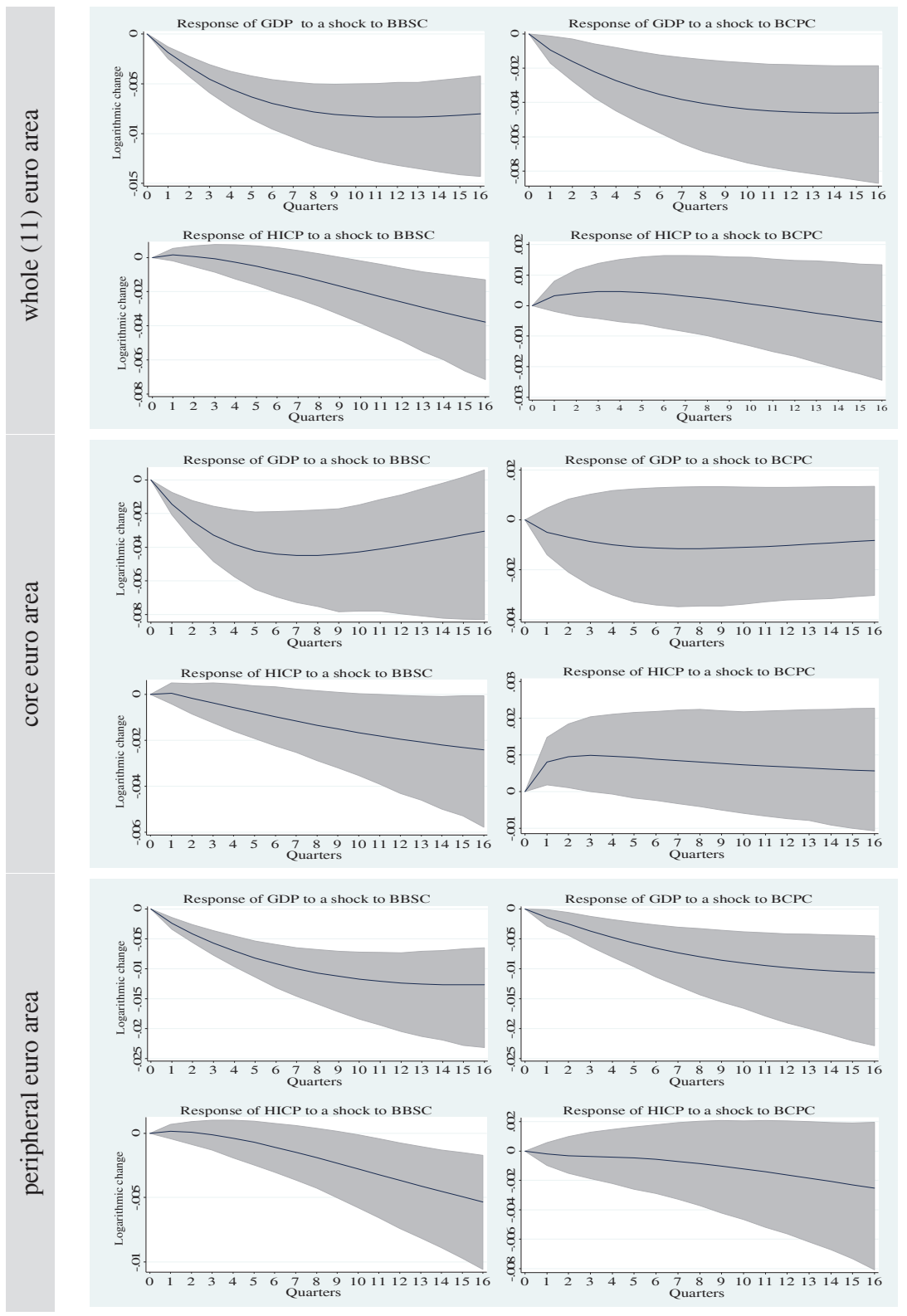

Notes: The plots present the (cumulative impulse) responses of the real GDP and HICP to a one standard deviation adverse shock (i.e., increase) to the BBSC and BCPC, respectively, over the period of 16 quarters from the shock. The black lines are the estimated cumulative impulse responses, while the shaded area shows a 95 percent (Monte Carlo) bootstrapped (with 1000 replications) confidence interval.

Source: Authors' calculations 
Again, a non-homogenous response is observed between the two groups of countries: GDP growth is significantly negatively affected only in the peripheral euro area.

\subsection{The robustness of the results}

The robustness of the results presented in Figures 2-5 is verified by alternative specifications of the baseline model represented by equation (1). We first checked whether the way the volume of loans is measured affects the results. For this purpose, we used an alternative definition of volume of loans, namely, notional loans. ${ }^{19}$ The results support the baseline model's results. ${ }^{20}$

As part of the robustness check, we also considered ordering of endogenous variables different from those in the baseline model. First, we re-ordered the BBSC and BCPC variables, placing the former last and the latter next to last. Different from the baseline model assumption, with this reordering we assume that the banks' capital position constraints contemporaneously affect borrowers' balance sheet constraints. The assumption implies that the borrowers' balance sheet constraints are more likely to respond to the banks' capital position constraints. With this assumption, we implicitly increase the relative importance of banks' capital position constraints over borrowers' balance sheet constraints in the credit standards setting and their macroeconomic effects. This alternation of the baseline model is reflected in a greater magnitude of response of the GDP, HICP, and business volume growth to a shock to the BCPC and a smaller response to a shock to the BBSC when compared to the baseline model. Other cumulative impulse responses are in line with the baseline's model.

In the next robustness check, we changed the order of the EONIA and the Eurosystem's balance sheet volume variables, placing the latter before the former. The results of the baseline model remain robust to this specification.

The robustness of the results (cumulated impulse responses) and their economic interpretation were also tested against the alternative measure of monetary policy stance of the Eurosystem. Instead of using EONIA and the Eurosystem balance sheet size as proxies for the Eurosystem's monetary policy stance, only one indicator for monetary policy was used - the shadow policy rate of the Eurosystem as defined and calculated by $\mathrm{Wu}$ and $\mathrm{Xia}$ (2015). We found that the cumulative

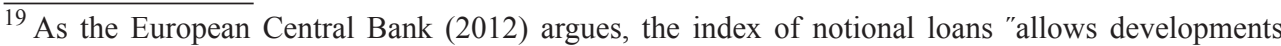
in the series to be presented without the effects that non-transactions would have on the growth rates of stocks." The index is calculated following European Central Bank (2012) as a chain index $\mathrm{I}(\mathrm{t})=\mathrm{I}(\mathrm{t}-1) \mathrm{x}[1+\mathrm{F}(\mathrm{t}) / \mathrm{S}(\mathrm{t}-1)]$, where $\mathrm{F}(\mathrm{t})$ is loan transactions during quarter $\mathrm{t}$ and $\mathrm{S}(\mathrm{t}-1)$ is outstanding loans volume at the end of the previous quarter.

${ }^{20}$ The results (cumulative impulse responses) of all the robustness checks are not presented here but are obtainable from the authors.
} 
impulse responses of the BBSC and BCPC to a shock to the shadow rate are larger than to a shock to EONIA. This is expected because now only one variable accounts for the monetary policy stance whereas in the baseline model two variables are used. As opposed to the baseline model, the HICP does not significantly respond to the shock to the BBSC variable. Other main findings from the cumulated impulse response functions analysis of the baseline model remain robust to this alternative specification.

The next robustness check consisted of verifying the time-stability of the broad credit and the bank capital channels of monetary policy for the euro area as whole. Following suggestion by one of reviewers, this robustness check was performed by inspecting the cumulative impulse responses calculated from the results of equation (1) for the period 2003Q1 - 2008Q3, i.e. period before the global financial crisis. Similar to the baseline model results, we found the monetary policy impulses working primarily through the policy rate and the broad credit channel. The responses of BBSC and the BCPC to the monetary policy shocks are found to be slightly stronger, while the responses of the business loans volume to the BBSC and the BCPC shocks smaller in scale as compared to the baseline model (i.e. the model for the whole observed time period). The pass-through of the monetary policy impulses from the (borrowers' s and the banks') balance sheets constraints to the economic activity (real GDP) and the HICP, however, is found to be different than in the baseline model: i) the shocks to the BBSC did not negatively impact the real GDP but only the HICP; ii) the broad credit and the bank capital channels were found to be interrelated - the shock to the BBSC negatively impacted the BCPC; the reverse was not the case. ${ }^{21}$ The results of this robustness check indicate that the monetary policy transmission channels are not static. A thorough analysis of the dynamics of the monetary policy channels exceeds the goals and the extent of this paper, but is certainly worth further analysis.

\section{Results and discussion}

Following some recent papers on monetary policy transmission mechanism (Lown and Morgan, 2006; Ciccarelli et al., 2013, 2015; Basset et al., 2014; Maddaloni and Peydró, 2011, 2012; Dajcman, 2016), the present paper showed how the BLS responses can be used to successfully identify the broad credit and the bank capital channel.

The results presented above (Figure 2) show that a tightening Eurosystem's monetary policy shock results in the euro area banks' credit standards tightening that is due to increased borrowers' balance sheet and banks' capital position constraints.

$\overline{{ }^{21} \text { The results of the }} 2003 \mathrm{Q} 1-2008 \mathrm{Q} 3$ estimation are available upon request. 
The effect of monetary policy shock is stronger in the stressed, peripheral euro area which is consistent with the theoretical prediction (e.g. Bernanke and Gertler, 1995; Markovic, 2006; Bernanke, 2007; Van den Heuvel, 2007) and empirical evidence (Ciccarelli et al., 2013, 2015). It is worth stressing that euro area banks see a contractionary monetary policy shock having a greater negative impact on the borrowers' balance sheets than on the banks' capital position.

In the non-frictionless credit markets, credit standards are an important mechanism of loan distribution (Lown and Morgan, 2006). Cumulative impulse response functions presented in Figure 3 show that in the euro area credit standards do determine credit activity which implies that the bank loans market is nonfrictionless. Our results thus support some earlier findings (e.g. Hempell and Sørensen, 2010; Ciccarelli et al., 2013, 2015).

An important contribution of this paper to the literature consists in showing that for the Eurosystem the broad credit channel is more relevant than the bank capital channel. Monetary policy shocks more significantly affect aggregate credit market activity and other macroeconomic aggregates (the real GDP growth and inflation) by working through the former channel than the later. Following a monetary policy shock, the real GDP growth responds more strongly and sooner than inflation - a results that is familiar from the literature (e.g., Lown and Morgan, 2006; Basset et al., 2014; Ciccarelli et al., 2013, 2015).

The theory (Markovic, 2006) predicts that the broad credit and the bank capital channels are interrelated. Our results provide confirmative evidence and show that they are more strongly related in the peripheral than core euro area.

Heterogeneity in policy transmission mechanism within the euro area is the main policy implication of the present research. The difference between the core and peripheral euro area's monetary policy transmission channels in the aftermath of the global financial crisis has already been witnessed (see Ciccarelli et al., 2013), but not for the bank capital channel. Given the financial stress in the peripheral euro area (manifested also in the borrowers' balance sheets and bank capital position constraints), a single standard monetary policy of Eurosystem does not fit the whole euro area. Policy measures that help to alleviate the borrowers' and banks' capital position constraints in the peripheral euro area countries are vital for the economic recovery in this part of the euro area. After the standard measures of Eurosystem's monetary policy have been exhausted, the nonstandard policy measures, conducted by the Eurosystem from October 2008, e.g. the covered bond purchase programme, an extension of the list of eligible collateral in Eurosystem credit operations, the securities markets programme, the covered bond purchase programmes, the longterm refinancing operations, the outright monetary transactions, the targeted longerterm refinancing operations, and the asset-backed securities purchase programmes, have contributed to easing of financial constraints of the economic agents in the 
euro area periphery (see e.g. Micossi, 2015; European Central Bank, 2015). The nonstandard monetary policy measures of the Eurosystem, as the results of the paper show, have the capacity to affect loan activity and recovery in the euro periphery.

\section{Conclusion}

Bearing in mind the relevance of bank lending for the euro area's enterprise sector and monetary policy transmission, this paper has examined the relevance of the broad credit and the bank capital channels of monetary policy in the euro area. The channels are identified with data from the Euro Area Bank Lending Survey.

The results of this survey have important implications for the monetary policy in the euro area. They show that the evidence for the relevance of the broad credit channel is strong. The channel is important for the core as well as the peripheral countries. Empirical evidence in support of the bank capital channel is less strong; the results imply that the impact of the monetary policy impulses on the macroeconomic variables through this channel are about half the size of that for the broad credit channel and that the channel may be relevant only for the peripheral countries. One of the findings of the paper is also that the broad credit and the bank capital channels of monetary policy transmission are interrelated, more so in the peripheral than in the core euro area. The results thus show that the euro area cannot be treated as a homogenous group when designing and evaluating the effects of monetary policy. The hypothesis of the paper is thus accepted.

The results of this survey complement the literature on the functioning of the non-standard monetary policy in the aftermath of the global financial crisis. They indicate that the balance nonstandard monetary policy of the Eurosystem works via the broad credit channel, but not via the bank capital channel.

\section{References}

Abrigo, M.R.M., Love I. (2016) "Estimation of Panel Vector Autoregression in Stata", The Stata Journal, Vol. 16, No. 3, pp. 778-804.

Andrews, D.W.K., Lu B. (2001) "Consistent model and moment selection procedures for GMM estimation with application to dynamic panel data models", Journal of Econometrics, Vol. 101, No. 1, pp. 123-164, doi: 10.1016/ S0304-4076(00)00077-4.

Bassett, F.W., Chosak M.B, Driscoll J.C., Zakrajsek E. (2014) "Changes in Bank Lending Standards and the Macroeconomy", Journal of Monetary Economics, Vol 62, No. 1, pp. 23-40, doi: 10.1016/j.jmoneco.2013.12.005. 
Bauer, D. M., Rudebusch G.D. (2015) “Monetary Policy Expectations at the Zero Lower Bound", Federal Reserve Bank of San Francisco Working Paper 2013-18.

Benito, A.T., Jamie N.R., Waldron M., Wood R. (2006) "House Prices and Consumer Spending", Bank of England Quarterly Bulletin, Summer 2006.

Bernanke, B.S. (2007) “The Financial Accelerator and the Credit Channel". In The Credit Channel of Monetary Policy in the Twenty-first Century Conference, Federal Reserve Bank of Atlanta, Atlanta, Georgia, June 15, 2007. Available at: $<$ https://www.federalreserve.gov/newsevents/speech/bernanke20070615a.htm> [Accessed: October 22, 2016].

Bernanke, B.S., Gertler M. (1989) "Agency costs, net worth, and business fluctuations", American Economic Review, Papers and Proceedings, Vol. 78, No. 2, pp. 435-9.

Bernanke, B.S., Gertler M. (1995) "Inside the Black Box: The Credit Channel of Monetary Policy Transmission", Journal of Economic Perspectives, Vol. 9, No. 4, pp. 27-48, doi: 10.1257/jep.9.4.27.

Bernanke, B.S., Lown C.S. (1991) "The Credit Crunch", Brookings Papers on Economic Activity, Vol. 2, No. 2, pp. 205-39, doi: 10.2307/2534592.

Boeckx J., Dossche M., Peersman G. (2014) "Effectiveness and Transmission of the ECB's Balance Sheet Policies", National Bank of Belgium Working Paper No. 275.

Boivin, J., Kley M.T., Mishkin F.S. (2010) "How has the monetary transmission mechanism evolved over time?", FEDS Working Paper No. 26, doi: 10.2139/ ssrn. 1783786.

Busch, U., Scharnagl M., Scheithauer J. (2010) "Loan Supply in Germany During the Financial Crisis", Deutsche Bundesbank Discussion Paper Series 1 05/2010.

Cappiello, L., Kadareja, A., Sørensen, C.K., Protopapa, M. (2010) "Do Bank Loans and Credit Standards have an Effect on Output? A Panel Approach for the Euro Area?". ECB Working Paper No. 1150.

Carlstrom, C., Fuerst, T. S. (1997) "Agency costs, net worth, and business fluctuations: a computable general equilibrium analysis", American Economic Review, Vol. 87, No. 5, pp. 893-910.

Carlstrom, C.T., Fuerst T.S., Paustian M. (2010) "Optimal Monetary Policy in a Model with Agency Costs", Journal of Money, Credit and Banking. Vol 42, No. 1, pp. 37-70, doi: 10.1111/j.1538-4616.2010.00329.x.

Cecchetti, S. G. (1995) "Distinguishing Theories of the Monetary Transmission Mechanism", Federal Reserve Bank of St. Louis Review, May/June 1995, pp. 83-97.

Christensen, I., Dib A. (2008) "The financial accelerator in an estimated New Keynesian model", Review of Economic Dynamics, Vol. 11, Issue 1, pp. 155178, doi: 10.1016/j.red.2007.04.006. 
Christiano, L.J., Eichenbaum M., Evans C.L. (1996) "The effects of monetary policy shocks: Evidence from the flow of funds", Review of Economics and Statistics, Vol. 78, No. 1, pp. 16-34, doi: 10.2307/2109845.

Ciccarelli, M., Maddaloni, A., Peydró, J.L. (2013) "Heterogeneous transmission mechanism: Monetary policy and financial fragility in the Euro area", Economic Policy, Vol 28, No. 75, pp. 459-512, doi: 10.1111/1468-0327.12015.

Ciccarelli, M., Maddaloni A., Peydró J.L. (2015) “Trusting the bankers. A new look at the credit channel of monetary policy", Review of Economic Dynamics, Vol 18, Issue 4, pp. 979-1002, doi: 10.1016/j.red.2014.11.002.

Cúrdia, V., Woodford M. (2010) "Credit frictions and optimal monetary policy", BIS Working Papers No. 278.

Dajcman, S. (2016) "The Bank Lending Channel of Monetary Policy and its Macroeconomic Effects: Evidence from a Sample of Selected Euro Area Countries", Engineering Economics, Vol. 27, Issue 2, pp. 124-133, doi: 10.5755/j01.ee.27.2.12647.

De Fiore, F., Tristani O. (2013) "Optimal Monetary Policy in a Model of the Credit Channel", The Economic Journal, Vol. 123, Issue 571, pp. 906-931, doi: 10.1111/j.1468-0297.2012.02558.x.

European Central Bank (2012) "Manual on mfi balance sheet statistics", Frankfurt: ECB.

European Central Bank (2015) "The transmission of the ECB's recent non-standard monetary policy measures", ECB Economic Bulletin, Issue 7. Frankfurt: European Central Bank.

Gambacorta L., Hofmann B., Peersman G. (2014) "The Effectiveness of Unconventional Monetary Policy at the Zero Lower Bound: A Cross-Country Analysis", Journal of Money, Credit and Banking, Vo. 46, No. 4, pp. 615-642, doi: 10.1111/jmcb.12119.

Gambacorta, L., Marques-Ibanez, D. (2011) "The Bank Lending Channel Lessons From the Crisis", ECB Working Paper Series No. 1335.

Gambacorta, L., Mistrulli E. (2004) "Does bank capital affect lending behavior?", Journal of Financial Intermediation, Vol 13, Issue 4, pp. 436-457, doi: 10.1016/j.jfi.2004.06.001.

Gertler, M., Gilchrist, S. (1993) "The Role of Credit Market Imperfections in the Monetary Transmission Mechanism: Arguments and Evidence", The Scandinavian Journal of Economics, Vol. 95, No. 1, pp. 43-64, doi: 10.2307/3440134.

Gertler, M., Gilchrist. S. (1994) "Monetary Policy, Business Cycles, and the Behavior of Small Manufacturing Firms", The Quarterly Journal of Economics, Vol. 109, No. 2, pp. 309-40, doi: 10.2307/2118465.

Hatzius, J. (2005) "Housing Holds the Key to Fed Policy", Goldman Sachs Global Economics Paper No. 137. 
Hempell, H.S., Sørensen K. (2010) "The impact of supply constraints on bank lending in the euro area - crisis induced crunching?", ECB Working Paper Series, no. 1262.

Im, K. S., Pesaran M. H., Shin Y. (2003) "Testing for unit roots in heterogeneous panels", Journal of Econometrics, Vol. 115, No. 1, pp. 53-74, doi: 10.1016/ S0304-4076(03)00092-7.

Kanngiesser, M., Martin R., Maurin L., Moccero, D. (2017) “Estimating the impact of shocks to bank capital in the euro area", ECB Working Paper Series No. 2077.

Kashyap, A.K., Stein J.C., Wilcox D.W. (1993) "Monetary Policy and Credit Conditions: Evidence from the Composition of External Finance", American Economic Review, Vol. 83, Issue 1, pp. 78-98.

Kishan, R.P., Opiela T.P. (2000) "Bank Size, Bank Capital, and the Bank Lending Channel”, Journal of Money, Credit and Banking, Vol. 32, No. 1 (Feb., 2000), pp. 121-141, doi: 10.2307/2601095.

Kishan, R.P., Opiela T.P. (2006) "Bank capital and loan asymmetry in the transmission of monetary policy", Journal of Banking and Finance, Vol 30, Issue 1, pp 259-85, doi: 10.1016/j.jbankfin.2005.05.002.

Kiyotaki, N., Moore J. (1997) “Credit cycles”, Journal of Political Economy, Vol 105, No 2, pp. 211-48, doi: 10.1086/262072.

Leeper, E.M., Sims C.A., Zha T. (1996) "What does monetary policy do?", Brookings Papers on Economic Activity, Vol. 27, No. 2, pp. 1-78, doi: $10.2307 / 2534619$.

Lombardi, M.J., Zhu F. (2014) "A shadow policy rate to calibrate US monetary policy at the zero lower bound", BIS Working Papers No. 452.

Love, I.,Zicchino, L. (2006) "Financial development and dynamic investment behavior: Evidence from Panel VAR", Quarterly Review of Economics and Finance, Vol. 46, No. 2, pp. 190-210, doi: 10.1016/j.qref.2005.11.007.

Lown, C.S., Morgan D.P. (2006) "The credit cycle and the business cycle: new findings from the Loan officer opinion survey", Journal of Money, Credit, and Banking, Vol. 38, No. 6, pp. 1575-1597, doi: 10.1353/mcb.2006.0086.

Maddaloni, A., Peydró J. L. (2011) "Bank risk-taking, securitization, supervision and low interest rates: evidence from US and euro area lending standards", Review of Financial Studies, Vol. 24, No. 6, pp. 2121-2165, doi: 10.1093/rfs/ hhr015.

Maddaloni, A., Peydró J. L. (2012) "The low monetary rates paradox, banking stability and credit: evidence from the euro area", Paper presented at the 12th Jacques Polak Annual Research Conference at the International Monetary Fund, Washington, D.C., November 10-11, Available at: <https://www.ecb.europa.eu/ events/pdf/conferences/rolecred/Maddaloni_Peydro_Jan2012_ijcb_all.pdf?52b da50181d3828df59d51b18fec9666> [Accessed: December 12, 2016]. 
Markovic, B. (2006) "Bank capital channels in the monetary transmission mechanism", Bank of England Working Paper No. 313, doi: 10.2139/ssrn.965470.

Meral, G. (2015) "The Effect of bank Size and Bank Capital on the bank Lending Channel for Turkish Banks", American Scientific Research Journal for Engineering, Technology, and Sciences (ASRJETS), Vol 12, No. 1, pp. 1-28.

Micossi, S. (2015). "The Monetary Policy of the European Central Bank (20022015)", CEPS Special Report No. 109/May 2015. CEPR.

Nickell, J.S. (1981) "Biases in Dynamic Models with Fixed Effects”, Econometrica, Vol. 49, No. 6, pp. 1417-26, doi: 10.2307/1911408.

Oliner, S.D., Rudebusch, G.D. (1996) "Is there a broad credit channel of monetary policy?", FRBSF Economic Review, No. 1, pp. 3-13.

Peek, J., Rosengren E.S. (2012) "The role of banks in the transmission of monetary policy”, In Berger, A.N., Molyneux, P., Wilson, J.O.S. ed., The Oxford Handbook of Banking (1 ed.), Oxford: Oxford University Press, doi: 10.1093/ oxfordhb/9780199640935.013.0010.

Persyn, D., Westerlund, J. (2008) "Error Correction Based Cointegration Tests for Panel Data", Stata Journal, Vol 8, No. 2, pp. 232-241.

Peydró, J.L. (2010) "Discussion of "The Effects of Bank Capital on Lending: What Do We Know and What Does It Mean?", International Journal of Central Banking, Vol 6, No. 4, pp. 55-69.

Van den Heuvel, S.J. (2002a) "Does Bank Capital Matter for Monetary Transmission?", FRBNY Economic Policy Review, May 2002.

Van den Heuvel, S.J. (2002b) "Banking conditions and the effects of monetary policy: Evidence from U.S. states", Federal Reserve Bank of San Francisco Working Paper.

Van den Heuvel, S.J. (2007) "The Bank Capital Channel of Monetary Policy", The Wharton School, University of Pennsylvania, mimeo.

Warner E.J., Georges C. (2001) "The credit channel of monetary policy transmission: evidence from stock returns", Economic Inquiry, Vol. 39, Issue 1, pp. 74-85, doi: 10.1111/j.1465-7295.2001.tb00051.x.

Watanabe, W. (2007) "Prudential regulation and the 'credit crunch': Evidence from Japan”, Journal of money credit and banking, Vol 39, Issue 1-2, pp 639-65.

Westerlund, J. (2007) "Testing for Error Correction in Panel Data", Oxford Bulletin of Economics and Statistics, Vol. 69, No. 6, pp. 709-748, doi: 10.1111/j. 14680084.2007.00477.x.

Wu J. C., Xia, F.D. (2015) "Measuring the Macroeconomic Impact of Monetary Policy at the Zero Lower Bound", Chicago Booth Research Paper No. 13-77, doi: $10.2139 /$ ssrn.2321323. 


\title{
Monetarni transmisijski kanal asimetričnih informacija (neto imovine dužnika) i kapitaliziranosti poslovnih banaka u središnjem i perifernom području Eurozone ${ }^{1}$
}

\author{
Silvo Dajcman ${ }^{2}$, Josip Tica ${ }^{3}$
}

\begin{abstract}
Sažetak
Cilj rada je identificirati i procijeniti učinke transmisije impulsa monetarne politike kroz kanal asimetričnih informacija (neto imovine dužnika, odnosno vrijednosti kolaterala) $i$ kapitaliziranosti poslovnih banaka u zemljama jezgre $i$ periferije Eurozone. U procijeni se koristi Euro Area Banking Lending anketa za potrebe identifikacije promjena u promatranim kanalima transmisije. Nakon identifikacije, pomoću prikupljenih podataka i panel vektorskog autoregresijskog modela procjenjuje se efekt konvencionalnih i nekonvencionalnih impulsa monetarne politike na BDP, inflaciju i obujam kredita. Rezultati ukazuju kako su promatrani kanali monetarne transmisije korelirani, kako je kanal asimetričnih informacija (neto imovine dužnika) relativno važniji od kanala kapitaliziranosti poslovnih banaka, te kako je kanal kapitaliziranosti poslovnih banaka relativno važniji od kanala asimetričnih informacija u zemljama periferije.
\end{abstract}

Ključne riječi: monetarna politika, transmisijski mehanizmi, kreditiranje poslovnih banaka, nekonvencionalna monetarna politika

JEL klasifikacija: E44, E5, G21

1 Istraživanje je sufinancirano sa strane Javne agencije za istraživačke aktivnosti Republike Slovenije (temeljni program P5-0023 (A) i od strane Hrvatske zaklade za znanost, projekt “Održivost ekonomske politike i razvoja u Hrvatskoj”, IP-2013-11-7031, akronim SCrEPoDe.

2 Docent, Sveučilište u Mariboru, Ekonomsko-poslovni fakultet, Razlagova 14, 2000 Maribor, Slovenija. Znanstveni interes: ekonomska politika, ekonomska teorija, financije. Tel: +386222 90 275,e-mail: silvo.dajcman@um.si (kontaktosoba).

${ }^{3}$ Redoviti profesor, Sveučilište u Zagrebu, Ekonomski fakultet Zagreb, Trg J.F. Kennedy 6, 10000 Zagreb, Hrvatska. Znanstveni interes: gospodarstvo Hrvatske, makroekonomija, strukturne promjene, tranzicija, ekonomski rast. Tel.: +3851238 3142. Fax: +385 1238 3333. E-mail: idruzic@efzg.hr. 